\title{
Decolourization of Methylene Blue by Rhodococcus Strain UCC 0003
}

\author{
Maegala Nallapan Maniyam, Fridelina Sjahrir, and Mohanapriya Hari
}

\begin{abstract}
Methylene blue is widely utilized as biological stains, in printing and as commercial textile dye. The increasing presence of textile dye in wastewater for instance represents environmental hazards. Therefore, there is a significant interest in developing cost effective and environmentally friendly methods for methylene blue removal from industrial wastewater. Taking this into consideration, in the present study, twenty three locally isolated Rhodococcus strains were examined as biological tools for decolourization of methylene blue. Among the tested microorganisms, five locally isolated Rhodococcus strains demonstrated promising ability to decolourize methylene blue as evidenced by the change in the colour of the dye from dark blue to pale blue on nutrient agar plates. One particular strain namely Rhodococcus strain UCC 0003 formed clear zone around the colonies of the bacteria with the biggest diameter of $2.0 \pm 0.1 \mathrm{~cm}$ after 2 days of cultivation time. This strain demonstrated good growth and completely decolourized $0.1 \mathrm{~g} / \mathrm{L}$ methylene blue after 5 days of incubation period. Secondary characterization was carried out by comparing the ability of resting cells and immobilized cells of Rhodococcus strain UCC 0003 for efficient methylene blue removal. The results showed that the highest percentage of methylene blue decolourization was achieved by using polyurethane foam cubes as the immobilization matrix resulting in $83^{a} \pm 1 \%$ compared to that of $63^{b} \pm 3 \%$ when resting cells was employed as the biocatalyst. These findings clearly indicated that the immobilized cells of Rhodococcus strain UCC 0003 has a huge potential as biological tool to remediate actual wastewater containing methylene blue.
\end{abstract}

Index Terms-Decolourization, immobilization, methylene blue, Rhodococcus.

\section{INTRODUCTION}

One of the most commonly used dyes in the textile industry is a heterocyclic aromatic compound with the molecular formula $\mathrm{C}_{16} \mathrm{H}_{18} \mathrm{~N}_{3} \mathrm{SCl}$ known as methylene blue [1]. Methylene blue can have various harmful effects even though this dye is not strongly hazardous [2]. Rapid breathing could occur upon inhalation while ingestion through mouth could cause burning sensation, nausea,

Manuscript received May 20, 2018; revised July 20, 2018. The authors would like to acknowledge Universiti Selangor (Unisel), Malaysia for providing the internal Bestari Research Grant (GPB/02-UNISEL17/ST-021) to support this research work.

Maegala Nallapan Maniyam is with the Center for Foundation and General Studies/Institute of Bio-IT Selangor, Universiti Selangor, Jalan Zirkon A7/A, Seksyen 7, 40000 Shah Alam, Selangor Darul Ehsan, Malaysia (e-mail: maegala_81@yahoo.com,maegala@unisel.edu.my).

Fridelina Sjahrir is with the Faculty of Engineering and Life Sciences, Universiti Selangor, Jalan Timur Tambahan, 45600 Bestari Jaya, Selangor Darul Ehsan, Malaysia (e-mail: fridelina@unisel.edu.my).

Mohanapriya Hari is with the Faculty of Engineering and Life Sciences, Universiti Selangor, Jalan Timur Tambahan, 45600 Bestari Jaya, Selangor Darul Ehsan, Malaysia (e-mail: monahari95@gmail.com). vomiting, diarrhea and gastritis [2]. Moreover, severe symptoms such as abdominal and chest pain, chronic headache, profuse sweating, mental confusion, painful micturation and methemoglobinemia can be experienced through ingestion of large dose of this dye [2]. Hence, it is necessary to treat the wastewater containing methylene blue generated from textile industry which is highly coloured and contaminated to comply with the legislative requirement and decrease the seriousness of water pollution [3]. Many chemical and physical methods such as flotation, coagulation/flocculation, filtration, ozonation, photocatalysis, electrolysis, Fenton treatment process and adsorption on activated carbon have been reported to date for removal of textile dye from wastewater [4]. However, these methods of treatment are usually inefficient and expensive [5]. Among these methods, biological treatment has been found to be superior since the utilization of biological species provides high selectivity, economical method and competent removal efficiency in the elimination of methylene blue [4].

The genus Rhodococcus in particular has interesting application in biotechnology and bioremediation since the genus is composed by highly adaptable bacteria capable of tolerating high amounts of a wide range of toxic compounds [6]. In addition, it has been proven that these microorganisms have the ability to develop and exist in diverse temperate and extreme surroundings such as highly polluted soils and water and nutrient or oxygen-limited condition without affecting the rate of biodegradation of pollutants [6]. However, the application of microorganisms in biodegradation has some challenges such as short term stability under certain conditions, complexity in recovery and non-reusability. Therefore, continuous effort has been carried out to improve the stability and activity of the potential biocatalyst through the technology of immobilization.

Biodegradation using immobilized cells may be a viable option due to its many advantages such as easy separation of cells for further use, enhancement of chemical stability and many more [4]. There are reports available on the use of immobilized cells to biodegrade methylene blue [4], [7], however, no works have been carried out on testing the ability of immobilized cells of Rhodococcus strains to biodegrade methylene blue to the best of our knowledge. Hence, in the present study, twenty three locally isolated Rhodococcus strains were screened on methylene blue to identify the most competent strain capable of decolourization and growth on the colourant. In addition, the most competent strain will be encapsulated in different support matrix namely calcium alginate and polyurethane foam. This protocol is carried out to examine the methylene blue-decolourizing activity of the immobilized cells in comparison to whole cells. 
This research is the first attempt on the use of Rhodococcus for decolourization of methylene blue and the findings suggested that the immobilized mode of the strain will be able to provide a promising technique for the decolourization of actual textile wastewater containing methylene blue.

\section{MATERIALS AND METHODS}

\section{A. Chemicals}

All chemicals used in this study were of analar grade and commercially available. The chemicals were obtained either from Merck (Germany), Sigma (USA) or Fisher Scientific (Singapore).

\section{B. Microorganisms}

Twenty-three Rhodococcus strains were used in this study. The isolates were obtained from Unisel Culture Collection Unit, Institute of Bio-IT Selangor, Universiti Selangor. These strain were locally isolated from various sources in Peninsular Malaysia by the research group previously. The microorganisms were kept in bead form in deep freezer at $-80^{\circ} \mathrm{C}$ and were resuscicated on nutrient agar plate for further use in the preparation of inoculum.

\section{Screening of Methylene Blue-Decolourizing Rhodococcus Strain}

Nutrient agar solution was prepared by using $20 \mathrm{~g}$ of nutrient agar added with $1 \mathrm{~L}$ of deionized water. Then, the solution was autoclaved at $121{ }^{\circ} \mathrm{C}$ for 15 minutes (HVE-50 Hirayama, Japan). Once autoclaved, the solution was let to cool until 60 to $70{ }^{\circ} \mathrm{C}$ and then added with $0.1 \mathrm{~g}$ of methylene blue dye. Approximately 20 to $25 \mathrm{~mL}$ of methylene blue agar solution was poured into petri dishes before it was solidified under sterile condition. These petri dishes were then covered and UV- sterilized for 15 minutes (Biosafety Cabinet 4ft-EN12469, ESCO Micro (M) Sdn. Bhd.).

The available twenty three Rhodococcus strains were streaked on the plates and incubated at $30{ }^{\circ} \mathrm{C}$ for 14 days, respectively (MEMMERT 108L Incubator INB500, Germany). The growth of bacterial strains, colour changes and possible formation of colourless zone around the colonies of the Rhodococcus which signify the decolourization activities were monitored for 14 days. The fastest growing bacterial strain of Rhodococcus with the largest formation of colourless zone will be selected for further characterization and secondary screening.

\section{Preparation of Starter Culture}

The nutrient broth solution was prepared by dissolving $8 \mathrm{~g}$ of nutrient broth with $1 \mathrm{~L}$ of deionised water and sterilized prior to inoculation of a loop full of Rhodococcus strain UCC 0003. The culture was then incubated in an incubator shaker (S1600R (B3L) Lab Companion, Jeiotech, Korea) at temperature of $30^{\circ} \mathrm{C}$ and agitation of $160 \mathrm{rpm}$ for 24 hours in duplicate. After 72 hours, the growth of starter culture was observed by measuring its optical density reading at wavelength of $600 \mathrm{~nm}\left(\mathrm{OD}_{600}\right)$ by using ultraviolet visual (UV-Vis spectra) spectrophotometer using Biospectrophotometer Biomate 3, Thermo Scientific (USA) with distilled water as blank. The $\mathrm{OD}_{600}$ value of starter culture was maintained at 1.2 to 1.3 prior to inoculation into the production medium to generate resting cells.

\section{E. Preparation of Resting Cells}

Seed culture of $5 \%(\mathrm{v} / \mathrm{v})$ was inoculated into production medium containing $8 \mathrm{~g}$ of nutrient broth in $1 \mathrm{~L}$ of deionised water. The production medium was left to shake for 72 hours at $30{ }^{\circ} \mathrm{C}$ and $160 \mathrm{rpm}$. The cells were then harvested by centrifugation at $4{ }^{\circ} \mathrm{C}, 16000 \times g$ for 30 minutes (Eppendorf $5702 \mathrm{R}$, South Asia) and subjected to washing with phosphate buffer ( $\mathrm{pH} 7)$ thrice. Finally, the collected Rhodococcus strain UCC 0003 cells were stored in phosphate buffer and refrigerated at $4{ }^{\circ} \mathrm{C}$ until further use as resting cells and for the preparation of immobilized cells.

\section{F. Preparation of Immobilized Cells}

The preparation of immobilized cells of Rhodococcus strain UCC 0003 in calcium alginate and polyurethane foam followed the protocols established by [8] with minor modifications. Resting cells amounting to $25 \mathrm{~mL}(4 \mathrm{~g} / \mathrm{L}$ dry cell weight) was used for immobilization. Control was prepared without the addition of resting cells.

\section{G. Decolourization of Methylene Blue by Resting Cells and Immobilized Cells of Rhodococcus Strain UCC 0003}

An amount of $25 \mathrm{~mL}$ of methylene blue solution $(0.2 \mathrm{~g} / \mathrm{L})$ was transferred into a $250 \mathrm{~mL}$ of Erlenmeyer flask and added with $25 \mathrm{~mL}$ of resting cells, $25 \mathrm{~mL}$ of heat-killed cells, 20 PUF cubes (corresponding to $25 \mathrm{~mL}$ resting cells) and 50 calcium alginate beads (corresponding to $25 \mathrm{~mL}$ resting cells). The flasks were prepared in triplicate for each type of inoculum. The flasks were then placed in an incubator at $30{ }^{\circ} \mathrm{C}$ for 24 hours. Heat-killed cells were prepared using 25 $\mathrm{mL}$ of resting cells autoclaved at $121{ }^{\circ} \mathrm{C}$ for 15 minutes. Heat-killed cells were used to determine the ability of Rhodococcus strain UCC 0003 to perform biosorption. Samples were harvested in triplicate at 0 hour and 24 hours of incubation period for decolourization assay, respectively. Cell leakage as well as the free cell content immobilized on both support matrices after encapsulation were quantified by calculating the dry cell weight. Immobilization yield was determined following protocols described in [9] by substituting protein content with dry cell weight.

\section{H. Analytical Methods}

\section{Decolourization assay}

Approximately $1 \mathrm{~mL}$ of sample was centrifuged at 16000 $\times g$ for 30 minutes at $4{ }^{\circ} \mathrm{C}$ at 0 hour and 24 hours of incubation period, respectively. Then, the supernatant was collected to determine the percentage of decolourization and the pellet was proceeded with dry cell weight determination. The decolourizing activity was expressed in terms of percent of decolourization by calculating the decrease in the absorbance for methylene blue dye at wavelength $620 \mathrm{~nm}$. Decolourization activity $(\%)$ was calculated as $[(\mathrm{A}-\mathrm{B}) / \mathrm{A}] \times$ $100 \%$.

$\mathrm{A}=$ initial absorbance

$\mathrm{B}=$ observed absorbance

Determination of dry cell weight

Empty Eppendorf tubes $(1.5 \mathrm{~mL})$ were weighed on a 
weighing balance (Sartorius TE214S, Germany) and the readings were recorded. The tubes were then placed in the biohazard safety cabinet and UV sterilized for at least 15 minutes. Approximately, $1 \mathrm{~mL}$ of sample or other appropriate volumes containing resting cells was withdrawn aseptically from the flask into the tube and centrifuged at $4{ }^{\circ} \mathrm{C}, 16000 \times$ $g$ for 15 minutes. After centrifugation, the supernatant was removed and the pellet at the bottom of Eppendorf tube was left to dry overnight at $60{ }^{\circ} \mathrm{C}$. After 24 hours, the Eppendorf tubes were weighed again with dried pellets and the readings were recorded.

\section{Statistical Analysis}

All experiments were conducted in triplicate and the values obtained were reported as means \pm standard error. The standard error was calculated by using Microsoft Excel version 2013. The comparison between groups was performed using one way analysis of variance (ANOVA) IBM SPSS version 23 with post hoc analysis by Duncan test. $\mathrm{p}<0.05$ was considered statistically significant. The results were ranked from a (most preferable) to c (least preferable).

\section{RESUlTS AND DisCUSSION}

\section{A. Screening of Methylene Blue-Decolourizing Rhodococcus Strain}

The decolourization of all twenty three locally isolated Rhodococcus strains grown on $0.1 \mathrm{~g} / \mathrm{L}$ methylene blue for 14 days is as shown in Table I.

TABLE I: DECOLOURIZATION OF METHYLENE BLUE BY RHODOCOCCUS STRAINS

\begin{tabular}{|c|c|c|c|}
\hline $\begin{array}{c}\text { Rhodococcus } \\
\text { strains }\end{array}$ & $\begin{array}{c}\text { Colour } \\
\text { changes }\end{array}$ & Growth & $\begin{array}{c}\text { Incubation } \\
\text { period (days) }\end{array}$ \\
\hline UCC 0001 & No change & $*$ & 14 \\
\hline UCC 0002 & $\begin{array}{c}\text { Blue to lighter } \\
\text { blue (paler) }\end{array}$ & $* *$ & 7 \\
\hline UCC 0003 & $\begin{array}{l}\text { Blue to } \\
\text { colourless }\end{array}$ & $* * *$ & 5 \\
\hline UCC 0004 & No change & $*$ & 14 \\
\hline UCC 0005 & $\begin{array}{c}\text { Blue to lighter } \\
\text { blue (paler) }\end{array}$ & $* *$ & 10 \\
\hline UCC 0006 & No change & $*$ & 14 \\
\hline UCC 0007 & $\begin{array}{l}\text { Blue to lighter } \\
\text { blue (paler) }\end{array}$ & $* *$ & 8 \\
\hline UCC 0008 & No change & $*$ & 14 \\
\hline UCC 0009 & No change & $*$ & 14 \\
\hline UCC 0010 & $\begin{array}{l}\text { Blue to lighter } \\
\text { blue (paler) }\end{array}$ & $*$ & 14 \\
\hline UCC 0011 & $\begin{array}{l}\text { Blue to lighter } \\
\text { blue (paler) }\end{array}$ & $* * *$ & 8 \\
\hline UCC 0012 & No change & $*$ & 14 \\
\hline UCC 0013 & No change & $*$ & 14 \\
\hline UCC 0014 & No change & $*$ & 14 \\
\hline UCC 0015 & $\begin{array}{c}\text { Blue to lighter } \\
\text { blue (paler) }\end{array}$ & $*$ & 14 \\
\hline UCC 0016 & No change & $*$ & 14 \\
\hline UCC 0017 & No change & $*$ & 14 \\
\hline UCC 0018 & $\begin{array}{l}\text { Blue to lighter } \\
\text { blue (paler) }\end{array}$ & $* *$ & 9 \\
\hline UCC 0019 & No change & $*$ & 14 \\
\hline UCC 0020 & No change & $*$ & 14 \\
\hline UCC 0021 & No change & $*$ & 14 \\
\hline UCC 0022 & No change & $*$ & 14 \\
\hline UCC 0023 & $\begin{array}{c}\text { Blue to lighter } \\
\text { blue (paler) }\end{array}$ & $* *$ & 10 \\
\hline
\end{tabular}

Growth indicator: *poor, **moderate/fair, ***good

Screening of twenty three locally isolated Rhodococcus strain on $0.1 \mathrm{~g} / \mathrm{L}$ methylene blue. Incubation was carried out for 14 days at $30{ }^{\circ} \mathrm{C}$. Control set was prepared with the absence of Rhodococcus strains on the plate.

A total of sixteen Rhodococcus strains namely UCC 0001, UCC 0004, UCC 0006, UCC 0008, UCC 0009, UCC 0010, UCC 0012, UCC 0013, UCC 0014, UCC 0015, UCC 0016, UCC 0017, UCC 0019, UCC 0020, UCC 0021 and UCC 0022 showed poor growth after an incubation period of 14 days at $30{ }^{\circ} \mathrm{C}$. These strains failed to change the colour of methylene blue and were not able to form colourless zones around the colonies of the respective strains. This observation clearly showed that these Rhodococcus strains were unsuccessful to decolourize the methylene blue dye due to high toxicity level which inhibit the growth of strains on the media [10]. These strains did not exhibit further growth even after prolonged incubation for 21 days.

Moderate growth was observed for Rhodococcus strains UCC 0002, UCC 0005, UCC 0007, UCC 0018 and UCC 0023, respectively. These strains were able to decolourize methylene blue dye after 14 days of cultivation time. Even though the strains showed moderate growth, no colourless zones were formed around the colonies. However, the media with methylene blue dye became paler when compared to control after 7 days of incubation for these strains. The colour of strains turned dark blue when the strains started to decolourize methylene blue and it clearly demonstrated that these strains were able to absorb the methylene blue dye. Due to toxicity of methylene blue dye, these strains were uncapable to decolourize the media fully after 14 days of incubation.

In this experiment, particularly two strains exhibited good growth on methylene blue media which were Rhodococcus strain UCC 0003 and Rhodococcus strain UCC 0011. Rhodococcus strain UCC 0011 demonstrated the presence of colourless zones around the colonies after 8 days of incubation time. Interestingly, the colonies of Rhodococcus strain UCC 0003 became white after going through the decolourization process which was different from the original orange colour of the strain as shown in Fig. 1. Among these two isolates, Rhodococcus strain UCC 0003 completely decolourized $0.1 \mathrm{~g} / \mathrm{L}$ of methylene blue after an incubation period of 5 days and the colonies recorded around $2 \mathrm{~cm} \pm 1.0 \mathrm{~cm}$ diameter of colourless zones after 2 days of cultivation time as shown in Fig. 1.

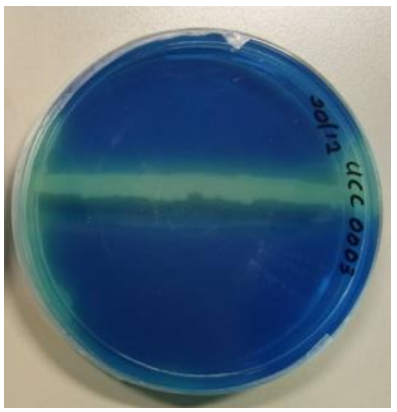

(A)

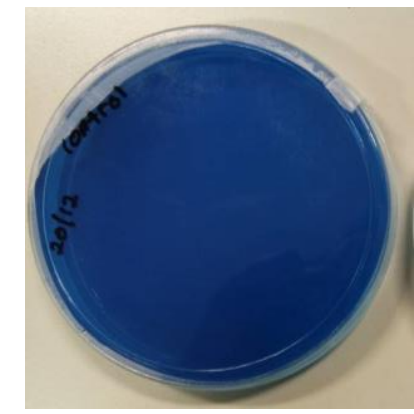

(B)
Fig. 1. (A) Rhodococcus strain UCC 0003 after 2 days of cultivation and (B) control.

In this study, Rhodococcus strain UCC 0003 was incubated with $0.1 \mathrm{~g} / \mathrm{L}$ of methylene blue dye which was then 
completely decolourized within 5 days as shown in Fig. 2.

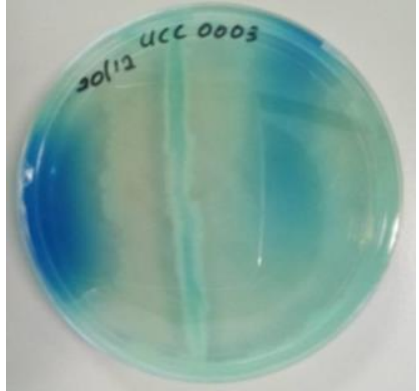

(A)

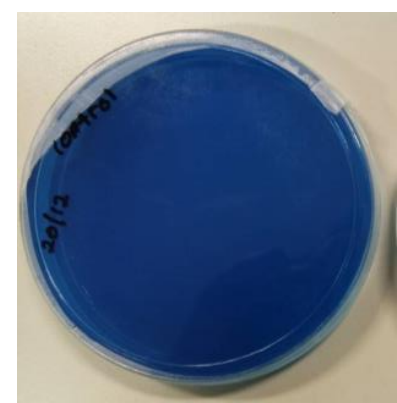

(B)
Fig. 2. (A) Rhodococcus strain UCC 0003 after 5 days of cultivation and (B) control.

Among the twenty three locally isolated Rhodococcus strains involved in methylene blue decolourization, Rhodococcus strain UCC 0003 emerged as the most competent strain for the decolourization of methylene blue within a short period of 5 days incubation. Rhodococcus strain UCC 0003 was subjected to further decolourization of methylene blue in the form of resting cells and immobilized cells, respectively.

\section{B. Decolourization of Methylene Blue by Resting Cells and Immobilized Cells of Rhodococcus Strain UCC 0003}

Interestingly, in all types of support matrices, none of the immobilized system showed a measurable cell leakage. This was due to speed of agitation and time reaction at $0 \mathrm{rpm}$ and 24 hours, respectively. In addition to that, research work by [11] mentioned no cell leakage occurred when the cells immobilized via entrapment method was used since these techniques created protective barrier around the immobilized microorganisms and therefore prevented cell leakage. In addition, negligible loss of methylene blue was detected in each control system ruling out abiotic loss of the colourant.

TABLE II: DECOLOURIZATION OF METHYLENE BLUE By RESTING CELLS AND IMMOBILIZED CELLS OF RHODOCOCCUS STRAIN UCC 0003

\begin{tabular}{cccc}
\hline \hline Matrices & $\begin{array}{c}\text { Methylene blue } \\
\text { removal }(\%)\end{array}$ & $\begin{array}{c}\text { Cell } \\
\text { leakage } \\
(\mathrm{mg} / \mathrm{mL})\end{array}$ & $\begin{array}{c}\text { Immobilization } \\
\text { efficiency }(\%)\end{array}$ \\
\hline $\begin{array}{c}\text { Poly } \\
\text { urethane } \\
\text { foam }\end{array}$ & $83.0^{\mathrm{a}} \pm 1$ & $\begin{array}{c}\text { Not } \\
\text { detected }\end{array}$ & $98 \pm 1$ \\
$\begin{array}{c}\text { Calcium } \\
\text { Alginate } \\
\text { Resting } \\
\text { Cells }\end{array}$ & $23.0^{\mathrm{c}} \pm 2$ & $\begin{array}{c}\text { Not } \\
\text { detected }\end{array}$ & $98 \pm 1$ \\
$\begin{array}{c}\text { Heat } \\
\text { Killed } \\
\text { Cells }\end{array}$ & $63.0^{\mathrm{b}} \pm 3$ & - & - \\
\hline \hline
\end{tabular}

The immobilized cells of Rhodococcus strain UCC 0003 cells were exposed to $0.2 \mathrm{~g} / \mathrm{L}$ of methylene blue dye at $30^{\circ} \mathrm{C}$. Cell leakage is a measurement of the cells escaped from the matrices into the solution. The detailed procedure was described Materials and Methods section. Statistically significant difference $(\mathrm{p}<0.05)$ was observed among the tested matrices and ranked from the most favoured to the least favoured following alphabetical orders in subscript format $\left(\right.$ most favoured $={ }^{\mathrm{a}}$, least favoured $={ }^{\mathrm{c}}$ ).

Table II shows the dye removal efficiency by free and immobilized cells of Rhodococcus strain UCC 0003 in calcium alginate and polyurethane foam, respectively. There were not much differences between calcium alginate and heat killed (autoclaved) cells in terms of methylene blue removal $(p>0.05)$ with $23^{\mathrm{c}} \pm 2 \%$ and $19^{\mathrm{c}} \pm 2 \%$ decolourization, respectively indicating the occurrence of dye biosorption and/or adsorption onto the immobilization matrix. However, noticeable increase in the decolourization of dye amounting to $83^{\mathrm{a}} \pm 1 \%$ was observed when the cells immobilized in polyurethane foam was utilized, recording $32 \%$ higher methylene blue removal efficiency compared to that of the non-immobilized cells. Meanwhile, $63^{\mathrm{b}} \pm 3 \%$ of removal efficiency was noted when resting cells was used for the decolourization of methylene blue. Even though appreciable methylene blue-decolourizing activity was observed with free cell system which required a more straightforward procedure than immobilization [12], this form of biocatalyst is not practical for actual application in treating textile industry effluent due to cell washout [13].

These results showed that the immobilized cells of Rhodococcus strain UCC 0003 in polyurethane foam were more pronounced in decolourizing methylene blue dye exhibiting significantly higher rate of methylene blue removal as compared to other matrices $(p<0.05)$. Polyurethane foam was chosen as the best matrix of support for the decolourization of methylene blue dye as supported by previous findings. A study on the utilization of bacterial cells immobilized on polyurethane foam to treat denim industry wastewater has been reported [14]. The immobilization of bacterial cells on polyurethane foam provided significantly higher operational stability and longevity of cells compared to that of free cells and bacterial cells immobilized in calcium alginate which is in line with the current study [14]. It can be concluded that the decolourization and biodegradation of methylene blue can be carried out seamlessly using polyurethane foam as suitable support. Better performance in terms of bacterial growth and production of extracellular enzymes can be achieved using polyurethane-immobilized systems in comparison to resting cells [15]. In addition, this cell entrapment method is fast, cheap and required mild conditions for the reaction process.

\section{CONCLUSION}

Bacteria are a better option among numerous microorganisms as biocatalyst for the decolourization of methylene blue due to their rapid production of biomass and high biodegradation and/or biosorption performance. In the present study, locally isolated Rhodococcus strains were used to decolourize methylene blue. Rhodococcus strain UCC 0003 exhibited complete decolourization of $0.1 \mathrm{~g} / \mathrm{L}$ methylene blue after 5 days of incubation period. The immobilized cells of this strain in polyurethane foam were capable to perform $32 \%$ greater methylene blue-decolourizing activity compared to resting cells. Moreover, the immobilization allowed greater tolerance towards higher concentration of the dye enabling these biocatalysts to decolourize almost completely $0.2 \mathrm{~g} / \mathrm{L}$ methylene blue in 24 hours in comparison to resting cells. These findings provided the preliminary data for devising protocols for actual application of immobilized cells of Rhodococcus strain UCC 0003 in treating textile industry wastewater. Further study should be concentrated on optimizing the decolourization performance of the isolate by manipulating factors such as temperature, $\mathrm{pH}$, number of 
polyurethane foam cubes and size of polyurethane foam cubes.

\section{ACKNOWLEDGMENT}

This paper is dedicated to Prof (E) Dato' Dr Abdul Latif Ibrahim, who is an inspirational mentor and more importantly an outstanding scientist.

\section{REFERENCES}

[1] J. Z. Guo, L. Bing, L. Liu, and L. Kangle, "Removal of methylene blue from aqueous solutions by chemically modified bamboo," Chemosphere, vol. 111, pp. 225-231, September 2014.

[2] W. Zhang, D. Lei, Y. Han, and L. Haijiang et al., "Removal of methylene blue from aqueous solutions by straw based adsorbent in a fixed-bed column," Chemical Engineering Journal, vol. 173, no. 2, pp. 429-436, September 2011.

[3] Y. L. Pang and A. Z. Abdullah, "Current status of textile industry wastewater management and research progress in malaysia: A review," Clean-Soil, Air, Water, vol. 41, no. 8, pp. 751-764, August 2013.

[4] G. Upendar, D. Susmita, B. Pinaki, and D. Abhishek, "Bioremediation of methylene blue dye using Bacillus subtilis MTCC 441," Water Science and Technology, vol. 75, no. 7, pp. 1572-1583, April 2017.

[5] M. Imran, E. C. David, K. Azeem, H. Sabir, W. M. Muhammad, and A. Muhammad, "Microbial biotechnology for decolorization of textile wastewaters," Reviews in Environmental Science and Bio/Technology, vol. 14, no. 1, pp. 73-92, March 2015.

[6] D. Carvalho, C. C. R. Carla, S. S. Costa, P. Fernandes, I. Couto, and Mi. Viveiros, "Membrane transport systems and the biodegradation potential and pathogenicity of genus Rhodococcus," Frontiers in Physiology, vol. 5, pp. 133, April 2014.

[7] K. V. Radha, I. Regupathi, A. Arunagiri, and T. Murugesan, "Decolorization studies of synthetic dyes using Phanerochaete chrysosporium and their kinetics," Process Biochemistry, vol. 40, no. 10 , pp. 3337-3345, October 2005.

[8] M. N. Maniyam, F. Sjahrir, A. L. Ibrahim, and A. E. G. Cass, "Cyanide degradation by immobilized cells of Rhodococcus UKMP-5M," Biologia, vol. 67, no. 5, pp. 837-844, October 2012.

[9] M. N. Maniyam, A. L. Ibrahim, and A. E. G. Cass, "Enhanced cyanide biodegradation by immobilized crude extract of Rhodococcus UKMP-5M," Environmental Technology, pp. 1-13, October 2017.

[10] S. Tokiran, M. N. Maniyam, N. S. Yaacob, and A. L. Ibrahim, "Decolourization of textile dyes by Malaysian Rhodococcus strains," Indian Journal of Fundamental and Applied Life Sciences, vol. 6, no, 1, pp. 14-20, March 2016.

[11] Z. Bayat, M. Hassanshahian, and S. Cappello, "Immobilization of microbes for bioremediation of crude oil polluted environments: A mini review," The Open Microbiology Journal, vol. 9, pp 48, 2015.

[12] M. K. Kureel, S. R. Geed, B. S. Giri, B. N. Rai, and R. S. Singh, "Biodegradation and kinetic study of benzene in bioreactor packed with PUF and alginate beads and immobilized with Bacillus sp. M3." Bioresource Technology, vol. 242, pp. 92-100, October 2017.

[13] L. Tan, L. Hua, N. Shuxiang, and X. Bingwen, "Aerobic decolorization and degradation of azo dyes by suspended growing cells and immobilized cells of a newly isolated yeast Magnusiomyces ingens LH-F1," Bioresource Technology, vol. 158, pp. 321-328, April 2014.

[14] R. Rajendran, P. Prabhavathi, S. Karthiksundaram, S. Pattabi, S. Dinesh Kumar, and P. Santhanam, "Biodecolorization and bioremediation of denim industrial wastewater by adapted bacterial consortium immobilized on inert polyurethane foam (puf) matrix: A first approach with biobarrier Model," Polish Journal of Microbiology, vol. 64 , no. 4, pp. 329-338, 2015.

[15] M. Sultan, "Polyurethane for removal of organic dyes from textile wastewater," Environmental Chemistry Letters, vol. 15, no. 2, pp. 347-366, Jun 2017.

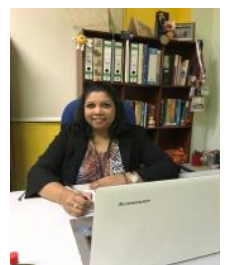

Maegala Nallapan Maniyam was born in Perak, Malaysia on $22^{\text {nd }}$ January 1981 . She received the BSc with education in chemistry from Universiti Teknolog Malaysia in 2002, the MSc in chemistry from Universit Teknologi Malaysia in 2003 and the Ph.D in biotechnology from Universiti Selangor-Imperial College London in 2013, respectively.

She joined the Faculty of Science and Education, Universiti Selangor as a Lecturer in 2005 and later appointed as a senior lecturer in 2014. She is currently attached with the Center of Foundation and General Studies, University Selangor. She is a Fellow at the Institute of Bio-IT Selangor, Universiti Selangor focusing on research and development in Life Sciences. She serves as a Reviewer in Frontiers in Environmental Microbiology, Science Publishing Group, USA, since 2016. Her current research interests include environmental biotechnology, green chemistry and microbiology.

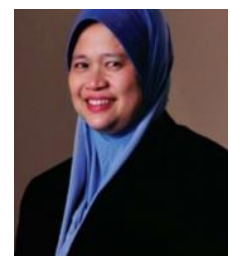

Fridelina Sjahrir received her Ph.D. degree in biotechnology from Universiti Selangor, Malaysia in 2014. Since then, she has been with the Faculty of Engineering and Life Sciences, where she is currently the deputy dean of academic.

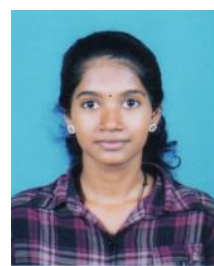

Mohanapriya Hari is currently pursuing her BSc in industrial biotechnology at Universiti Selangor, Malaysia. She has recently completed her final year project which contributed in the preparation of the paper substantially. 